Discipline

\title{
HAS THE FIREARMS PROTOCOL HELPED REDUCED ARMED VIOLENCE?
}

\author{
Anna Alvazzi del Frate, Emile LeBrun, Christian Ponti
}

Title: Has the firearms protocol helped reduced armed violence?

\begin{abstract}
This paper focuses on the long-term objective of the Firearms Protocol supplementing the United Nations Convention against Transnational Organized Crime to reduce certain kinds of armed violence associated with the misuse of firearms. More than 15 years after the Protocol has come into force, the authors ask how its possible impacts on armed violence might be assessed; indicate key challenges for such an enterprise, and suggest directions for future work in this area, towards the establishment of a measurement tool which could help inform the recently established Review Mechanism of the Protocol.
\end{abstract}

Keywords: firearms trafficking; transnational organized crime; armed violence; Firearms Protocol; treaty review mechanisms

Questo saggio si concentra sulla riduzione di certe forme di violenza armata perpetrate con le armi da fuoco, obiettivo a lungo termine del Protocollo sulle armi da fuoco, supplementare alla Convenzione delle Nazioni Unite contro la criminalità organizzata transnazionale. Quindici anni dopo la sua entrata in vigore, gli autori si interrogano su come misurare i possibili impatti del Protocollo sulla violenza armata, indicando le questioni chiave da affrontare e suggerendo alcune possibili direzioni future degli studi in quest'area, incluso lo sviluppo di uno strumento di misurazione, anche nell'ottica di informare il funzionamento del Meccanismo di riesame del Protocollo, recentemente istituito.

Parole Chiave: traffico di armi da fuoco; criminalità organizzata transnazionale; violenza armata; Protocollo sulle armi da fuoco; Meccanismi di riesame. 


\section{Introduction}

The international community's approach to illicit firearms proliferation began in the late 1990s as an attempt to tighten up and standardize national legal frameworks with the goal of reducing criminal access to guns. Addressing the armed violence that criminals and other actors commit with guns was an underlying rationale of arms control instruments developed through multilateral diplomacy at the UN. These instruments include the Protocol against the Illicit Manufacturing of and Trafficking in Firearms, their Parts and Components and Ammunition (hereafter the Protocol) and the UN Programme of Action on the illicit trade in small arms (hereafter UN PoA), ${ }^{1}$ negotiations for both of which began in 1997. Almost two decades later, it is worth returning to that rationale to ask whether the momentum of implementation has generated impacts in reducing violent firearm offenses. In particular, to ask if the Firearms Protocol made any difference in reducing criminal or other kinds of armed violence. ${ }^{2}$

When the United Nations Convention against Transnational Organized Crime (hereinafter UNTOC) was adopted in 2000, ${ }^{3}$ three supplementary protocols were elaborated, namely on trafficking in persons, on smuggling of migrants, and on firearms. ${ }^{4}$ The Firearms Protocol was the last of the three to enter into force, on 3

\footnotetext{
${ }^{1}$ Negotiations took place in New York and Vienna further to the Report of the Panel of Government Experts on Small Arms, UN Doc. A/Res/52/298, 27 August 1997 and the Report of the Expert Group Meeting on Gathering Information on and Analysis of Firearm Regulation (see Criminal Justice Reform and Strengthening of Legal Institutions: Measures to Regulate Firearms, Vienna, ECOSOC, E/CN.15/1997/4, 7 March1997.

See https://digitallibrary.un.org/record/248585/files/E_CN.15_1997_4-EN.pdf, and https://digitallibrary.un.org/record/234350/files/E_CN.15_1997_4_Corr.1-EN.pdf.

2 In this paper the authors use the following definition of armed violence: "the intentional use of illegitimate force (actual or threatened) with arms or explosives, against a person, group, community, or state, that undermines people-centred security and/or sustainable development" (Global Burden of Armed Violence 2008, Geneva, 2008, page 2). This definition does not include self-directed violence (suicide).

${ }^{3}$ GA Res. 55/25, 15 November 2000 (entered into force on 29 September 2003).

${ }_{4}^{4}$ Protocol to Prevent, Suppress, Punish Trafficking in Persons, Especially Women and Children, Supplementing the United Nations Convention Against Transnational Organized Crime, UN Doc. A/Res/55/25, 15 November 2000 (entered into force on 25 December 2003); Protocol Against the Smuggling of Migrants by Land, Sea and Air, Supplementing the United Nations Convention Against Transnational Organized Crime, UN Doc. A/Res/55/25, 15 November 2000, (entered into force on 28 January 2004); Protocol Against the Illicit Manufacturing of and Trafficking in Firearms, Their Parts and Components and Ammunition, Supplementing the United Nations Convention Against Transnational Organized Crime, UN Doc. A/Res/55/255, 31 May 2001.
} 
July 2005, and it celebrated its 15 th anniversary in 2020. Despite a relatively low level of ratification (as of August 2021 it counts 120 parties, as opposed to 190 parties to the UNTOC, 178 parties to the Protocol on Trafficking in Persons and 150 to the Protocol on Smuggling of Migrants), 5 it is a foundational global arms control instrument. It is also likely to gain further momentum thanks to the recently established UNTOC Review Mechanism (hereinafter Review Mechanism) ${ }^{6}$, whose monitoring activities cover the most relevant substantive provisions of the Protocol.

The Protocol, which is also the first legally binding global instrument on firearms, aims "to promote, facilitate and strengthen cooperation among States Parties in order to prevent, combat and eradicate the illicit manufacturing of and trafficking in firearms, their parts and components and ammunition". 7 By ratifying the Protocol, States make a commitment to criminalize certain activities, establish administrative crime prevention measures, and to cooperate internationally. ${ }^{8}$

The Protocol's immediate objectives are to constrain illicit manufacturing of and trafficking in firearms, and it shares with its parent Convention and the other protocols the ultimate goal of making the world safer for people, by reducing the negative impacts of these illicit practices, which endanger "[...] the well-being of people, their social and economic developments and their right to live in peace". ${ }^{9}$ This higher objective, which can be expressed either as a reduction of crime and armed violence or as an increase in safety and security, is in line with the 2030 Agenda for Sustainable Development (hereinafter 2030 Agenda). ${ }^{10}$ Among other objectives, the 2030 Agenda promotes peaceful and inclusive societies (Sustainable Development Goal 16, hereafter SDG16), to be achieved in part by reducing all forms of violence and related death rates (SDG Target 16.1) and a significant reduction in

\footnotetext{
5 https://www.unodc.org/unodc/en/treaties/CTOC/signatures.html(last visited on 4 October 2021).

${ }^{6}$ Conference of the Parties to the United Nations Convention against Transnational Organized Crime, Ninth Session, Vienna, 15-19 October 2018, Resolution 9/1, Establishment of the Mechanism for the Review of the Implementation of the United Nations Convention against Transnational Organized Crime and the Protocols thereto, CTOC/COP/2018/L.4/Rev.1, 19 October 2018; see Paragraph 6, infra.

${ }^{7}$ Art. 2 of the Protocol.

${ }^{8}$ See Paragraph 3, infra.

${ }^{9}$ See Preamble (Para. 1) of the Protocol.

10 UN Doc. A/Res/70/1, 15 September 2015, Transforming our world: the 2030 Agenda for Sustainable Development.
} 
illicit arms flows (SDG Target 16.4). ${ }^{11}$ The UN PoA, which was adopted on 20 July 2001, and the Arms Trade Treaty (hereinafter ATT) ${ }^{12}$, which entered into force in December 2014, share these long-term violence reduction and safety promotion goals.

The armed violence prevention objectives of these global arms control instruments express a critical challenge in many countries: approximately 40 per cent of all killings are committed with firearms globally. ${ }^{13}$ This general fact hides a heterogenous phenomenon: collective violence and individual inter-personal violence; legal civilian firearms and illicitly manufactured or trafficked guns. In the case of guns that become illicit because they have been diverted from their authorized users, the point of diversion from legal to illicit varies, and arms that are lost or stolen easily get into criminal hands. ${ }^{14}$ This is why a reduction in illicit arms flows - an objective towards which Protocol implementation aims - can be so important for advancing on the higher objective of reducing violence and increasing safety. With the passing of the Protocol's fifteenth anniversary of coming into force in 2020 , it is a valuable moment to begin thinking about its possible contribution and that of other international arms control instruments - in preventing and reducing armed violence.

How this might be done in practice was the focus of a recent discussion by the authors at the 24-hour Conference on Global Organized Crime on 10 November 2020,15 in which the authors raised some general considerations and potential challenges. Starting from that discussion, this paper adopts an interdisciplinary approach, focusing on both normative compliance and indicators for monitoring trends in armed violence, and considering how the two aspects relate. This assessment exercise, drawing on expertise from the crime control, armed violence

\footnotetext{
11 The General Assembly qualified these targets as "integrated and indivisible", ibidem, para. 5.

12 See Paragraph 2, infra.

${ }^{13}$ See Gergely Hideg and Anna Alvazzi del Frate, Still Not There: Global Violent Deaths Scenarios, 201930, Small Arms Survey, Briefing Paper, Geneva, February 2021, p. 3.

14 See UNODC, Global Study on Firearms 2020, https://www.unodc.org/unodc/en/firearmsprotocol/firearms-study.html, p. 32.

15 https://oc24.globalinitiative.net/1c/
} 
reduction, and arms control domains, aims to make some observations and provides suggestions for future work in this area.

It could also offer a useful piece of analysis and information to support States in approaching the Protocol's Review Mechanism, as well as consider the impact of the Protocol's implementation on meeting relevant SDG Targets. This is an area where academia and civil society organizations are uniquely positioned to play an important role.

\section{The Protocol and the international normative framework}

Since the Protocol was adopted, the international community's approach to firearms and firearms violence has evolved considerably. Further to initial data collected by a UN study in 1996-97,16 in 2001 a first global estimate of the distribution of small arms indicated that more than 50 percent were in the hands of civilians. ${ }^{17}$ Furthermore, poor handling of State responsibilities (such as stockpile management and prevention of illicit arms trade, including the capacity to intercept arms after conflicts, for example in the Western Balkans) were producing negative effects in terms of the uncontrolled spread of arms and related violence. Internationally agreed measures to improve State stockpile management, enhance civilian arms controls, and prevent diversion and illicit trafficking were therefore urgent.

Parallel to the negotiations for the Protocol in Vienna, diplomats in New York were negotiating what ultimately resulted in the PoA, adopted in July $2001^{18}$. This soft law instrument commits States to improving domestic legislation on small arms, import/export controls, and stockpile management. It was an important response to the growing awareness of the proliferation of illicit small arms among civilians and the lack of clear norms at the international level. In 2005, the PoA was

\footnotetext{
16 See Small Arms Survey 2001.Profiling the Problem, Oxford 2001, pp. 17-19.

17 Ibidem, at p. 89.

18 Report of the United Nations Conference on the Illicit Trade in Small Arms and Light Weapons in All Its Aspects, New York, 9-20 July 2001, UN Doc. A/CONF.192/15.
} 
supplemented by the International Tracing Instrument (ITI) ${ }^{19}$ which, for the purpose of tracing, requires States to ensure that firearms are properly marked and that records are kept. The PoA/ITI, whose review process has grown to include a range of guidance and references to evolving good practices, provides States with a framework for supplementing and strengthening the Protocol's basic legal requirements.

In 2013, the $\mathrm{ATT}^{20}$ was adopted, with the purpose to impose conditions on the legal trade of conventional arms among States parties and to link transfer authorizations to considerations of the humanitarian and human rights situations. Like the Firearms Protocol, the ATT is legally binding and, although different in scope (weaponry, and activities covered) ${ }^{21}$ they have roughly the same level of ratification. ${ }^{22}$

Meanwhile, other global norms and instruments have become intertwined with the underlying violence prevention and human rights promotion objectives of arms control agreements. Notably, UN Security Council Resolution (UNSCR) n. 1325 on Women, Peace and Security (2000), ${ }^{23}$ includes references to the international arms trade and the importance of disarmament. UNSCR 1325 has led to many follow-on resolutions that have become known collectively as the Women, Peace and Security (WPS) Agenda, and which contain frequent references to the importance of arms control and the negative impacts of conventional arms on vulnerable groups.

Furthermore, growing awareness of the impacts of armed violence on development led to the Geneva Declaration on Armed Violence and Development (2006), ${ }^{24}$ a like-

\footnotetext{
${ }^{19}$ Report of the Open-ended Working Group to Negotiate an International Instrument to Enable States to Identify and Trace, in a Timely and Reliable Manner, Illicit Small Arms and Light Weapons, UN Doc. A/60/88, 27 June 2005.

${ }^{20}$ UN Doc. A/RES/67/234, 2 April 2013 (entered into force on 24 December 2014).

21 See art. 4 of the Protocol and art. 2 of the ATT.

${ }^{22}$ On 4 October 2021, the ATT has 110 State parties to the 120 to the Firearms Protocol. However, a number of the world's largest arms exporters have not ratified the ATT.

23 UN Doc. S/RES/325, 31 October 2000.

${ }^{24}$ Available at https://www.genevadeclaration.org. The Geneva Declaration was adopted on 7 June 2006 by 42 states at a Ministerial Summit in Geneva. It was subsequently signed by a total of 113 countries. Between 2006 and 2015, the Declaration was the only instrument making a clear connection between uncontrolled proliferation of licit firearms, illicit trafficking in firearms, armed and crime violence, and human, social, and economic development.
} 
minded, high-level multi-lateral initiative launched by Switzerland and led by a core group of 15 States that promoted the voluntary declaration, ultimately signed by 113 States, as well as commissioning research to measure impacts and acting as a clearing house for best practices. ${ }^{25}$ By focusing on the violence-development nexus, the Geneva Declaration filled an important gap left by the Millennium Development Goals (MDGs). ${ }^{26}$

This gap was ultimately more fully addressed in September 2015 with the adoption of the 2030 Agenda, in which UN member States agreed that "Sustainable development cannot be realized without peace and security; and peace and security will be at risk without sustainable development". ${ }^{27}$ Goal 16 and specifically SDG Targets 16.1 and $16.4^{28}$ addressed the issues at the core of the Geneva Declaration, which in 2015 ceased to be an active process to support the new Agenda. ${ }^{29}$ With the adoption of SDG Target 16.4 on illicit arms flows, the 2030 Agenda for development became de facto a firearms control instrument. ${ }^{30}$

\footnotetext{
${ }^{25}$ See the three editions of the Global Burden of Armed Violence, a comprehensive study of the impacts of armed violence: Geneva Declaration Secretariat, Global Burden of Armed Violence 2008, Geneva, 2008; Geneva Declaration Secretariat, Global Burden of Armed Violence 2011: Lethal Encounters, Cambridge, 2011; Geneva Declaration Secretariat, Global Burden of Armed Violence 2015: Every Body Counts, Cambridge, 2015.

${ }^{26}$ See United Nations Millennium Declaration, UN Doc. A/RES. 55/2, 18 September 2000.

27 UN Doc. A/RES/70/1, para. 35, see footnote n. 10, supra.

${ }^{28}$ Goal 16 aims to "Promote peaceful and inclusive societies for sustainable development, provide access to justice for all and build effective, accountable and inclusive institutions at all levels". Goal targets include, inter alia, Target 16.1 "Significantly reduce all forms of violence and related death rates everywhere"; and Target 16.4 "By 2030, significantly reduce illicit financial and arms flows, strengthen the recovery and return of stolen assets and combat all forms of organized crime".

${ }^{29}$ Global Burden of Armed Violence 2015, Chapter 1, see footnote n. 25, supra.

${ }^{30}$ Progress towards Target 16.4 is measured by two indicators, namely: 16.4.1: "Total value of inward and outward illicit financial flows (in current United States dollars)", and 16.4.2: "Proportion of seized, found or surrendered arms whose illicit origin or context has been traced or established by a competent authority in line with international instruments".
} 
Discipline

\section{State obligations within the Protocol}

The Protocol aims at promoting and strengthening international cooperation and developing mechanisms to prevent, investigate and prosecute offences stemming from the illicit manufacturing of and trafficking in firearms. States who ratify the Protocol assume a legal obligation to adopt into their domestic legal frameworks necessary measures, including legislative and administrative ones, to ensure its implementation. ${ }^{31}$

Under Article 5, States parties commit to the criminalization of: illicit manufacturing of firearms, their parts and components and ammunition; illicit trafficking in firearms, their parts and components and ammunition; and falsifying or illicitly obliterating, removing, or altering the marking(s) on firearms required by Article 8 of this Protocol.

Under the Protocol, States parties also commit to some specific administrative measures aimed at identifying and tracing each firearm, namely:

a) applying unique marking at the time of manufacture of each firearm; requiring appropriate simple marking on each imported firearm; and ensuring appropriate unique marking at the time of transfer of a firearm from government stocks to permanent civilian use (Article 8);

b) the record-keeping of all the above and any other relevant information about firearms, by following specific modalities (Article 7);

c) the confiscation of illicitly manufactured or trafficked firearms (Article 6);

d) sharing information and cooperation in the tracing of firearms with other States parties (Articles 12 and 13).

Core obligations upon States parties finally include the establishment of a comprehensive export, import and transit authorization or licensing systems for firearms (Article 10).

While the words "armed violence" do not appear in the text of the Protocol or in its parent Convention, the concept is alluded to strongly in the first paragraph of the

${ }^{31}$ See Art. 1 para. 2 of the Protocol and Art. 34 para. 1 of UNTOC. 
Protocol's Preamble, which refers to "the harmful effects" of illicit firearms manufacturing and trafficking. ${ }^{32}$ It characterizes the need to address these activities and their effects as 'urgent'. Indeed, historical analysis of the considerations underlying the UNTOC and the Protocol shows that they were designed to address the economic and social consequences of organized crime, characterized as "typically much greater than the consequences of traditional forms of interpersonal violence and crime against property, thus posing a more serious threat to society and national economies".33 Transnational organized crime was therefore considered an amplifier of armed violence at multiple levels, both as modus operandi of organized criminal groups, and as a consequence of impunity or lack of rule of law.

It is notable that, more than 15 years after the coming into force of the Protocol, the violence reduction dimensions of this instrument still remains to be explored. The States parties to the Protocol have made relatively slow progress in monitoring and assessing its implementation at the national level, ${ }^{34}$ and this is one reason its potential impacts on violence reduction are obscure. That may soon change with the arrival of the Review Mechanism, discussed below.

\footnotetext{
32 See Preamble (Para. 1) of the Protocol. The word "violence" appeared in preliminary drafts of the Preamble and was struck only in the final text adopted by the GA; see Travaux Préparatoires of the negotiations for the elaboration of the United Nations Convention against Organized Crime and the Protocols thereto (https://www.unodc.org/pdf/ctoccop_2006/04-60074_ebook-e.pdf) pp. 593595). Similar provisions appear in the Preambles of the PoA (Para. 15) and ATT (Paras. 3 and 7).

${ }^{33}$ See Travaux Préparatoires of the negotiations for the elaboration of the United Nations Convention against Organized Crime and the Protocols thereto (https://www.unodc.org/pdf/ctoccop_2006/0460074_ebook-e.pdf) p. ix.

${ }^{34}$ Between 2004 and 2008, the Conference of the Parties to the UNTOC carried out a series of "informal" monitoring activities based on self-assessment in order to gather information on implementation of the Protocol. The Secretariat had received responses to the questionnaire from 55 Member States, of which 37 were parties, 10 were signatories and 8 were non-signatories to the Protocol; see Implementation of the Protocol against the Illicit Manufacturing of and Trafficking in Firearms, Their Parts and Components and Ammunition, supplementing the United Nations Convention against Transnational Organized Crime: consolidated information received from States, Report of the Secretariat, CTOC/COP/2006/8/Rev.1, 12 August 2008.
} 


\section{What can be measured?}

Further to the normative aspects, it would be desirable to develop an independent parallel tool to assess the potential violence reduction impacts of the Protocol and other arms control instruments. This tool, if built on a broad base of data collected in the framework of monitoring the SDGs plus additional primary data, would help fulfil State commitments arising not only from the Protocol but also the PoA, the ATT, the 2030 Agenda and the WPS Agenda. But identifying to what extent each process contributes to violence reduction is likely to be challenging. The Protocol and other related arms control instruments are likely to generate synergies, so it may be difficult to separate respective impacts.

For one thing, measuring the direct effects on violence of particular gun policies and laws is complicated by many factors that are difficult to control for. Available data has not allowed researchers to establish a clear relationship between firearm availability levels and firearm homicides at the global level, ${ }^{35}$ or to assess the impact of a single global gun policy intervention on homicides. Yet many studies identify causality or at least contributory effects of combined policies at the national or regional level. ${ }^{36}$

Furthermore, much of the information on armed violence and illicit arms proliferation and possession - especially from the most violent contexts - is weak, with incomplete data, often of poor quality (with incomplete time series and/or lacking disaggregation by sex and age of perpetrators and victims, context, type of weapon used). The improvement of data and development of indicators may become an objective per se.

\footnotetext{
35 See Global Burden of Armed Violence 2011, Chapter 3, p. 100; as well as the relevant analysis in the Global Burden of Armed Violence 2015, p. 79, footnote n. 25, supra.

36 See for example studies on the US (https://pubmed.ncbi.nlm.nih.gov/27842178/; https://www.bu.edu/articles/2019/state-gun-laws-that-reduce-gundeaths/;https://academic.oup.com/jpubhealth/advance-articleabstract/doi/10.1093/pubmed/fdab047/6225077);

Australia (https://www.rand.org/research/gun-policy/analysis/essays/1996-national-firearmsagreement.html); Brazil (https://pophealthmetrics.biomedcentral.com/articles/10.1186/s12963020-00222-3; https://revistapesquisa.fapesp.br/en/disarming-violence-2/).
} 
Implementation of, and compliance with, an international instrument is generally used as indicators of good performance by countries monitoring its effectiveness. ${ }^{37}$ National reports, statements and updates delivered at regular meetings or conferences of parties can include quantitative and qualitative information on progress in implementation. Monitoring at the international level may also compile and summarize the information received, for example, by using checklists for actions taken (yes/no) on agreement elements.

Such compliance indicators are indispensable but lack granularity and cannot measure progressive improvements. For example, the UNODC database SHERLOC 38 contains 51 pieces of national legislation from 32 States in response to implementation of the Protocol and a database of case law in firearms trafficking. ${ }^{39}$ This provides an important and growing (but still insufficient) source of information about the process of enacting international norms into domestic law and the challenging task to measure compliance with them. ${ }^{40}$

Nevertheless, when violence reduction is not a direct, but rather indirect, expected consequence of implementation - as is the case with the Protocol - this approach has limitations. To move beyond these limitations, a mixed set of research methodologies would be appropriate, incorporating access to official (and

\footnotetext{
37 Although implementation is typically a decisive requirement to achieve compliance, these two notions are conceptually distinct. On this point see, for instance, Kal Raustiala and Anne-Marie Slaughter, International Law, International Relations and Compliance, in The Handbook of International Relations, Walter Carlsnaes, Thomas Risse, Beth A. Simonds (eds.), London, 2002, at p. 539: "Implementation is the process of putting international commitments into practice: the passage of legislation, creation of institutions (both domestic and international) and enforcement of rules", while compliance refers to: "[...] a state of conformity or identity between an actor's behaviour and a specified rule".

38 https://sherloc.unodc.org/cld/en/st/home.html.

${ }^{39} \mathrm{~A}$ comprehensive review of data measuring the compliance of States parties with the Protocol is not available, but prosecutions of illicit firearms trafficking have historically been low. In this regard the UNDOC, Global Study on Firearms 2020 (see footnote n. 14, supra, at p. 12) argues that criminal justice responses tend to underplay the significance of firearms trafficking: "The evidence suggests that the criminal justice system focuses on firearms trafficking only in a relatively small percentage of the cases where it would be warranted - meaning firearms trafficking is a largely hidden phenomenon, only part of which comes to the surface".

${ }^{40}$ To this purpose Neil Boister, An Introduction to Transnational Criminal Law, 2nd edn., Oxford, 2018, at p. 412, interestingly pointed out: "it is relatively simple to measure when parties to suppression conventions fail to enact laws they have undertaken to enact" (implementation); on the contrary, it is harder to measure State compliance with international norms contained in the suppression conventions: "The failure to enforce them is more common but more difficult to ascertain".
} 
unofficial) crime, public health, and other datasets. As is the case in any evaluation process, the assessment should use SMART indicators (specific, measurable, accessible, reliable, and timely). Data should be public and transparent and of a high quality, with good disaggregation at all desired levels so as to capture impacts for all groups of population and communities. ${ }^{41}$ Specific indicators to capture the impacts of the Protocol may require fine tuning at the local level to reduce external influences on the minimum extent.

The SDGs include 231 unique indicators against which to measure progress. ${ }^{42}$ These reflect a major effort of the statistical community to provide quantitative measures of change over the period 2015-30. Nevertheless, targets within Goal 16 reveal some of the challenges of over-relying on quantitative indicators. For example, SDG Indicator 16.1 .1 supporting Target 16.1 on the reduction of lethal violence rates is highly exposed to the risk of showing an apparent reduction (thus a positive progress over time) due to underreporting, undercounting, or even data manipulation (for example by downgrading intentional homicide cases to unintentional ${ }^{43}$ ). Similarly, to measure progress towards a "significant reduction of illicit arms flows" (as foreseen by SDG Target 16.4), SDG Indicator 16.4.2 - on the proportion of firearms traced to their illicit origins - cannot capture much more than the ability of reporting countries to trace firearms. The official data collection mechanism for this indicator is the International Arms Flows Questionnaire (IAFQ), ${ }^{44}$ established by UNODC in consultation with UNODA. According to UNODC, countries successful in tracing firearms are more likely to report low seizure levels,

\footnotetext{
${ }^{41}$ As per 2030 Agenda's notable principle that "nobody should be left behind", SDG Target 17.18 calls for a significant increase in the availability of high-quality, timely and reliable data disaggregated by income, gender, age, race, ethnicity, migratory status, disability, geographic location and other characteristics relevant in national contexts.

${ }^{42}$ See https://unstats.un.org/sdgs/indicators/indicators-list/

${ }^{43}$ See John A. Eterno and Eli B. Silvermann, The Crime Numbers Game: Management by Manipulation, New York, 2012, cited in Wendy Ruderman, Crime Report Manipulation Is Common Among New York Police, Study Finds, in "The New York Times", 28 June 2012, https://www.nytimes.com/2012/06/29/nyregion/new-york-police-department-manipulatescrime-reports-study-finds.html

${ }^{44}$ See https://www.unodc.org/unodc/en/data-and-analysis/statistics/crime/iafq.html
} 
as opposed to some countries with high levels of seizures which are less successful in tracing. 45

A mixed methods approach will therefore be necessary to systematically integrate quantitative and qualitative data, with a view to generating a more complete and fully informed impact assessment.

To achieve this result, it will be necessary to carry out qualitative research, including surveys, in-depth interviews, and empirical fieldwork. Qualitative indicators could cover many aspects of the relationship between the State and firearms legislation, in connection with existing norms and their application, the awareness of basic facts relevant to the problem (such as types and extent of firearm violence) among the public and the judiciary, and the role and activity of civil society. These indicators can be correspondingly assessed using qualitative methods. One of the lessons of recent efforts to draw on both official and unofficial data sources to measure progress against violence reduction indicators is the central importance of qualitative data. ${ }^{46}$

It is necessary to consider a set of impact indicators, first of all lethal and non-lethal incidents involving firearms (legal and illicit), types of arms used in different categories of crime, as well as seizure data. ${ }^{47}$ The capacity to produce, collect and analyse such data varies considerably among countries. For example, the UNODC Global Study on Firearms 2020 indicates that 80 UN Member States - including

\footnotetext{
45 UNODC, Global Study on Firearms Trafficking 2020, see footnote n. 14, supra, p. 17.

46 "Monitoring and Implementing SDG16+: The Relevance of Non-Official Data and Indices for the 2030 Agenda for Sustainable Development", SDG16+ Data Initiative 2020 report https://www.idea.int/sites/default/files/news/news-

pdfs/\%5B18November2020\%5D_SDG16DI_Global_Report_2020_\%5BNewYorkOffice\%5D_\%5BAm andaSourek\%5D.pdf.

${ }^{47}$ UNODC, Global Study on Firearms Trafficking 2020, see footnote n. 14, supra, pp. 77-84. This broad set of indicators could build on existing global databases, for example, the global database of the SDG indicators (https://unstats.un.org/sdgs/indicators/database), the UNODC Global Study on Homicide and relevant database (https://www.unodc.org/unodc/en/data-and-analysis/global-study-onhomicide.html), the Global Burden of Disease (http://www.healthdata.org/gbd/publications), WHO mortality data (https://www.who.int/data/data-collection-tools/who-mortality-database), as well as national and local relevant indicators, but also specialized databases maintained by civil society such as the Global Firearms Holdings and the Global Violent Deaths databases (https://www.smallarmssurvey.org/databases).
} 
parties and non-parties to the Protocol - were able to respond to the IAFQ and some supplementary data could be found only for 27 additional countries (see Map 2). ${ }^{48}$

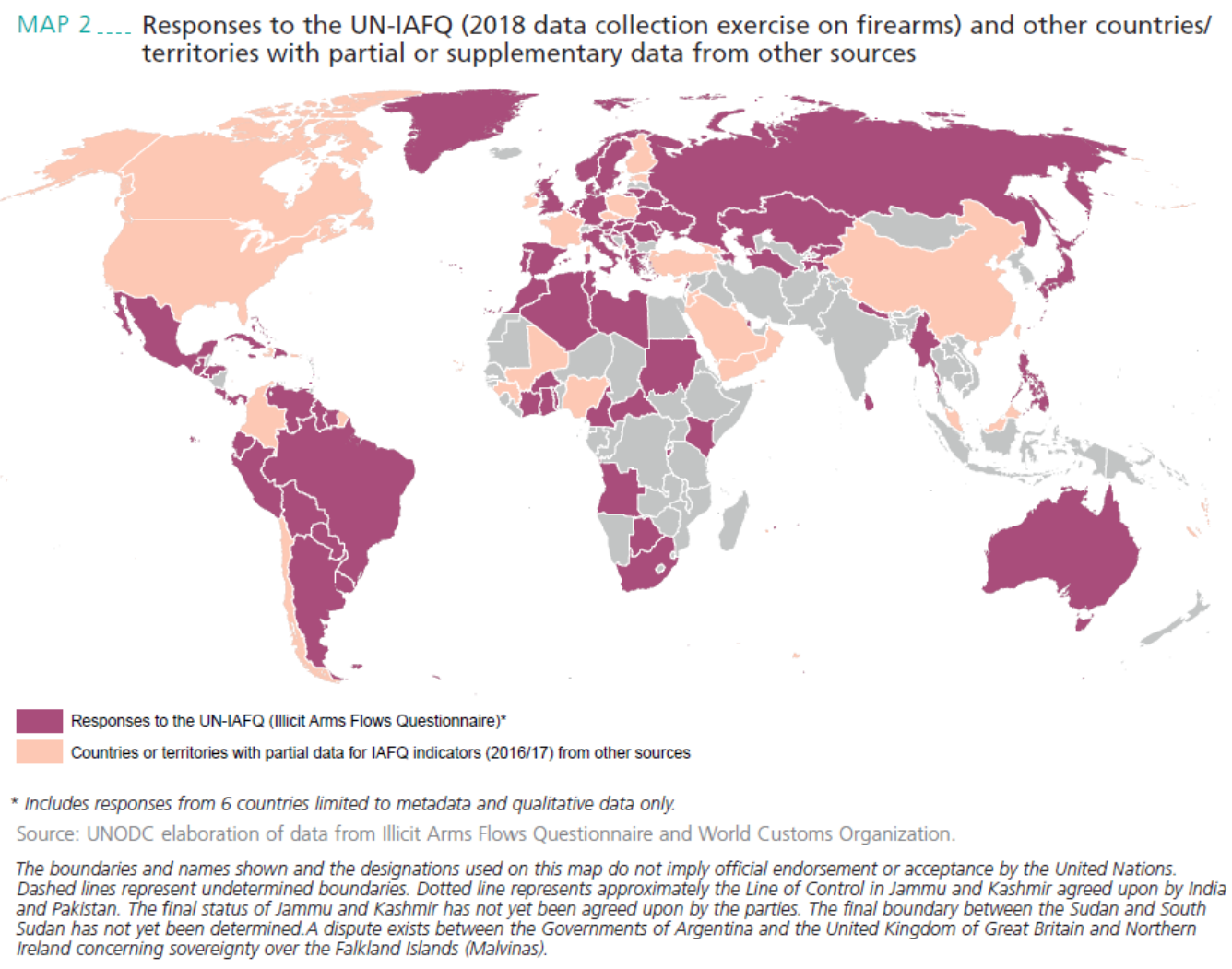

National statistical capacities and approaches differ significantly. Recent research carried out by the Small Arms Survey with UNODC and the African Union Commission included capacity support to a group of African States identify their own indicators for measuring (reductions of) illicit arms flows and impacts. ${ }^{49}$ While all States prioritized the importance of firearms killings, they also specified a range of other, locally-important indicators. These include, among others, data on civilian firearms licensing and registration; percentage of State-held firearms marked and recorded; locally-specific illicit arms flow indicators; numbers of firearms seized and/or destroyed; law enforcement operations and judicial cases dealing with illicit firearms trafficking; and an indicator of the existence of official standard operating

\footnotetext{
48 Ibidem, p. 17.

${ }^{49}$ Final report of the UNSCAR-funded project Strengthening national institutions in developing a system of indicators on firearms (unpublished) https://www.un.org/disarmament/unscar/sas/
} 
procedures for safe and secure stockpile management. This suggests that a framework for the assessment of impacts of the Protocol could include some common key indicators but should also be context-specific and flexible.

It should be noted, however, that there is significant regional variation in armed violence, and assessments will need to take this into account. This is one reason it may be difficult to establish a correlation between the (low/high) level of armed violence in a country and accession to/implementation of the Protocol. For example, scenarios in Latin American countries (where the odds of dying of violence are more than four times higher than the global average and about 60 percent of killings are committed with firearms ${ }^{50}$ ) are quite different from those in other regions characterized by lower levels of armed violence (such as Eastern Asia or Europe ${ }^{51}$ ). In these latter contexts, accession to the Firearms Protocol and other relevant instruments may be reflect a responsible action of multilateral diplomacy even in the absence of an emergent problem, thus reinforcing the existing arms control (and, by this logic, armed violence prevention) frameworks.

\section{A complex undertaking}

The idea of assessing a global firearms instrument for its potential impacts on armed violence makes intuitive sense. In fact, effective implementation of the international arms control regime, which includes the Protocol, is an essential component and a relevant contributor to achieving the SDG targets of a significant reduction in all forms of armed violence (Target 16.1) and of illicit arms flows (Target 16.4). ${ }^{52}$ In the

\footnotetext{
${ }^{50}$ See Gergely Hideg and Anna Alvazzi del Frate, Still Not There: Global Violent Deaths Scenarios, 201930 , cit., Table 2 (p. 6) and Figure 7 (p. 10).

51 Ibidem.

${ }^{52}$ See, for example, Glenn McDonald, Luigi De Martino, Measuring Illicit Arms Flows: SDG Target 16.4, Small Arms Survey, Research Note No 57, Geneva, May 2016, p. 1; and Glenn McDonald, Anna Alvazzi del Frate, Moshe Ben Hamo Yeger, Arms Control 2.0: Operationalizing SDG Target 16.4, Small Arms Survey, Briefing Paper, Geneva, October 2017, pp. 3-4. International commitments on arms control and crime prevention, when transformed into domestic law, ultimately aim at significantly reducing violence and harmful effects of arms misuse. Effective implementation is therefore a pre-requisite for progress.
} 
current context, therefore, developing a framework for assessing the impacts of the Protocol on armed violence reduction according to SDG 16 targets and indicators could be a valuable exercise.

Since the instrument is operationalized through the development of national laws and policies, any assessment would have to address multiple steps, while also disentangling its role from that of other instruments, and measuring the impacts of the Protocol-specific actions. As the Protocol is part of an evolving comprehensive and integrated set of international instruments focusing on the firearms problem, separating out the impacts of the Protocol may be challenging. To some degree, there is value in assessing the effects of all relevant measures together, and this is a potentially more straightforward enterprise. At the same time, isolating the impacts of the criminalization and other administrative measures of the Protocol would be valuable for identifying how those specific efforts relate to levels of armed violence. This is feasible at the level of association rather than causation.

Furthermore, different effects of the Protocol may relate to corresponding phases in the process of its operationalization at the national level: signature, ratification, initial implementation, subsequent State practices (including multiple enforcement actions by practitioners), with potentially very long delays between each of these steps. What is more, the motivations for States to accede to the Protocol can be very different: some may join because of the prominence of firearms in criminal violence within their borders; others may do so out of (regional or political) solidarity, opportunity, or other relevant considerations; or because they already have similar laws on their books and agree with the general approach. ${ }^{53}$ These underlying motivations may have implications for the robustness of implementation and, as a consequence, for any impacts on violence. For these reasons, the entire policy development and implementation process and sequencing needs to be taken into account in assessment efforts.

\footnotetext{
${ }^{53}$ For this reason, there may be a need to interrogate repositories of domestic legislation beyond the level of a simple checklist. Historical information on the development of legislation may provide crucial information. This type of analysis - relatively cumbersome - may be necessary to establish a baseline for assessing the impact of the Protocol in different countries.
} 
Since armed violence prevention is somewhat 'downstream' from the criminalization and other preventive measures that the Protocol requires States Parties to introduce, it will be necessary to consider and control for the potential impacts of other factors on armed violence beyond the Protocol, including other arms control efforts or completely unrelated developments. These include: broad socio-economic crises; the commencement or cessation of armed conflict; independently evolving trends in illicit manufacture and trafficking of firearms; natural phenomena (such as the covid-related pandemic) among others. In an ideal world we would have the capacity and means to empirically link illicitly manufactured or trafficked firearms (and ammunition) to specific acts of armed violence; in the real world, this may not be practical in many cases. Many impediments interfere with a direct impact assessment, including the lack of robust baseline data in relevant health, crime, and other datasets. ${ }^{54}$

It is also important to consider that the effects of any control measures may include displacement of the phenomena or the emergence of different scenarios. Trends in illicit firearm manufacture and trafficking are fluid and dynamic and can evolve in unexpected ways, both in response to enforcement efforts and other factors. For example, the banning of handguns in the United Kingdom and tighter EU-level firearm restrictions ${ }^{55}$ have undoubtedly helped reduce violence. ${ }^{56}$ But as handguns have become less available in these regions, convertible firearms have become more

\footnotetext{
54 See for example the analysis of availability of firearms data presented by UNODC in the Global Study on Firearms Trafficking 2020 (see footnote n. 14, supra); the analysis of availability of data on violent deaths presented in Gergely Hideg and Anna Alvazzi del Frate, Counting and Characterizing Global Violent Deaths: Current data sources, gaps and possible remedies, at the Global Registry of Violent Deaths (GReVD),2020,website https://grevd.org/; and the analysis of gender-relevant firearms datasets presented in Anna Alvazzi del Frate, Gergely Hideg and Emile LeBrun, Gender Counts: Assessing Global Armed Violence Datasets for Gender Relevance, Small Arms Survey, Briefing Paper, Geneva, March 2020.

${ }^{55}$ See the 1997 Firearms (Amendment) Acts, Violent Crime Reduction Act (2006), the Offensive Weapons Act (2019) of the United Kingdom, as well as the Directive (EU) 2017/853 of the European Parliament and of the Council of 17 May 2017 amending Council Directive 91/477/EEC on control of the acquisition and possession of weapons; in OJEU L 137/22, 24 May 2017.

${ }^{56}$ The UK reports a 35 percent decrease in firearm killings between 2010-2020. See Office of National Statistics of the UK, Homicide in England and Wales: Appendix Tables, Table 10 https://www.ons.gov.uk/peoplepopulationandcommunity/crimeandjustice/datasets/appendixtabl eshomicideinenglandandwales.
} 
visible, ${ }^{57}$ are more frequently seized and confiscated, ${ }^{58}$ and appear more frequently in different forms of violence. ${ }^{59}$ Legal frameworks need to be flexible enough to respond to this fluidity, ${ }^{60}$ and assessment efforts must also be wide enough to take account of these effects. There are also trends in firearms manufacturing technology, such as polymer weapons and 3D printing, that are highly relevant for enforcement efforts. ${ }^{61}$

Despite the general scarcity of official data in these areas, significant sources of relevant information already exist, as well as replicable methodologies. These include surveys and empirical research already conducted by UNODC and independent research organizations. ${ }^{62}$ There is a firm basis for developing national

\footnotetext{
${ }^{57}$ See Nicolas Florquin, Benjamin King, From Legal to Lethal: Converted Firearms in Europe, Small Arms Survey, Geneva, April 2018.

58 For example, in Denmark seizures of convertible alarm and gas pistols increased four times between 2014 and 2017. While in 2014 less than one-fifth of them had been converted, in the first months of 2017 this was the case with more than one in three. See Lina Grip, Illegal weapons, gangs and violent extremism in Denmark, Country study for the SAFTE project, Flemish Peace Institute, 2018, Table 4, p. 138 - https://www.flemishpeaceinstitute.eu/safte/publications.html.

${ }^{59}$ For instance, the 2015 terrorist attacks in Europe (Paris and Copenhagen) included, inter alia, the use of firearms that had been incorrectly deactivated or firearms assembled with badly deactivated components (as well as acoustic weapons being converted into real firearms). For an extensive analysis on the use of firearms (including converted and reactivated firearms) by terrorist groups in Europe see Nils Duquet, Kevin Goris, Firearms acquisition by terrorists in Europe. Research findings and policy recommendations of Project SAFTE, Flemish Peace Institute Brussels, 18 April 2018.

${ }^{60}$ Unlike the Protocol, which provides some flexibility with regard to national control regimes on deactivated weapons (Art. 9) and does not provide for a detailed discipline of conversion (although the definition of firearms under the Protocol includes all devices that "may be readily converted" into a firearm), recent European legislation [Directive (EU) 2017/853 (see footnote n. 55, supra) and Commission Implementing Regulation (EU) 2018/337 of 5 March 2018 amending Implementing Regulation (EU) 2015/2403 establishing common guidelines on deactivation standards and techniques for ensuring that deactivated firearms are rendered irreversibly inoperable, in $O J E U, \mathrm{~L}$ 65/1, 8 March 2018] establishes several regulatory measures on deactivated/reactivated and converted firearms; see Christian Ponti, An Appraisal of the European Union Legal Framework on Illicit Firearms Trafficking after Directive 2017/853/EU, in this Journal vol. 4 (2) 2018, pp. 13-34.

${ }^{61}$ For a cursory analysis of the actual effectiveness of the Firearms Protocol to address these issues see Responsiveness of the Firearms Protocol and national legislation to new and emerging threats relating to the illicit manufacturing of and trafficking in firearms, their parts and components and ammunition, Background paper prepared by the Secretariat, UN Doc. CTOC/COP/WG.6/2020/2, 14 January 2020, especially paras. 34-54. States' concerns about the criminal exploitation of new technologies such as 3D printing and polymer and modular weapons have been also an important stream of discussion in the UN PoA's review process. The PoA's Eighth Biennial Meeting of States will consider whether to establish an open-ended technical expert group on this issue in 2022; see UN General Assembly, Outcome of the Seventh Biennial Meeting of States to Consider the Implementation of the Programme of Action to Prevent, Combat and Eradicate the Illicit Trade in Small Arms and Light Weapons in All its Aspects, UN Doc. A/CONF.192/BMS/2021/CRP.2/Rev.1, 30 July 2021, para. 92.

62 Including, for example, the databases on homicides, firearms and other relevant data held by UNODC (see https://dataunodc.un.org/); the databases on Global Violent Deaths and Global
} 
violence assessment research efforts and indicators, which would draw on data collected to measure progress towards SDG Targets 16.1 and 16.4, especially. The extent to which States make other data available to researchers will influence how robust assessments can be, and how useful they can be in linking specific implementation efforts to violence reduction, thus enhancing the effectiveness of the Protocol's impacts for all States parties.

\section{Leveraging the Review Mechanism of the Protocol}

The establishment in 2018 of a Review Mechanism ${ }^{63}$ marks a promising step in the evolution of the implementation process and compliance with the Protocol--and progress in the critical assessment of its impact on armed violence. Officially launched in October 2020,64 it is mandatory on all States parties, although it does not provide for sanctions in case of non-participation. The Review Mechanism includes a general review that takes place in the plenary session of the Conference of the Parties to the UNTOC and country reviews. These encompass a selfassessment with the aim to gather information on implementation; 65 and a substantive desk peer evaluation component 66 in which each State's performance is

Firearms Holding of the Small Arms Survey (see https://www.smallarmssurvey.org/databases); the Global Database of the SDG indicators (see https://unstats.un.org/sdgs/unsdg), etc.

${ }^{63}$ See footnote n. 6, supra.

${ }^{64}$ Conference of the Parties to the United Nations Convention against Transnational Organized Crime, Tenth Session, Vienna, 12-16 October 2020, Resolution 10/1, Launch of the review process of the Mechanism for the Review of the Implementation of the United Nations Convention against Transnational Organized Crime and the Protocols thereto, CTOC/COP/2020/10, 3 November 2020.

65 The Review Mechanism will provide, in a period of 10 years, for a mandatory mutual evaluation in different cycles of all relevant substantive provisions of the Protocol. With the aim to review each thematic cluster of articles of the Protocol (criminalization, jurisdiction, prevention, law enforcement and international cooperation, etc.), the States under review complete the relevant sections of a selfassessment questionnaire on their implementation and compliance with the Protocol.

${ }^{66}$ Information may only be examined electronically remotely through the use of a new secure module of the knowledge management portal SHERLOC. Reviewing states are not allowed to carry out onsite visits to the peer reviewed country (for instance, this happens under the Organisation for Economic Co-operation and Development (OECD) Anti-Bribery Convention, whose monitoring system foresees a mechanism of mandatory country visits; under other peer review treaty bodies such as the United Nations Convention against Corruption (UNCAC) Review Mechanism on-site visits may take place, but only with the consent reviewed State). These visits which vary in scope (they typically include interviews, inspections, and meetings with the main stakeholders involved in the domestic implementation process) are of crucial importance to assess compliance by measuring the 
evaluated by two other States parties (with the assistance of the Secretariat and the active involvement of the State under review). ${ }^{67}$ The goal is to help the reviewed State improve its policymaking, adopt best practices, implement, and comply with the Protocol.

The Review Mechanism rules encourage States parties to involve relevant civil society stakeholders (academia, NGOs, and private sector) both in the consultation and the assessment phases. ${ }^{68}$ Involving research institutions early in the process would increase the inclusiveness, transparency, effectiveness, and legitimacy of the Review Mechanism.

Civil society is well placed to undertake broad consultations with the purpose to help governments to fully complete their self-assessment questionnaires. For instance, by gathering valuable non-official information and data, and developing multi-disciplinary research efforts on synergies and complementarity between the implementation of the Protocol and other global arms control instruments such as the ATT and PoA. ${ }^{69}$ Qualitative research, flexible indicators, rigorous, objective, and scientific findings could positively influence policymaking and enhance not only the implementation of the Protocol but its approaches to illicit firearms manufacture and trafficking and their connection to armed violence.

It is established that the reviewing States, at the final stage of each review phase for each State party, and in close cooperation with the State party under review (and with the assistance of the Secretariat), must prepare a list of observations. This represents an absolute novelty within the context of global small arms control instrument review processes. Assessment criteria for this country review report include any gaps and challenges in the implementation of the provisions under

actual practice of international norms within the State by practitioners, government, and law enforcement officials.

${ }^{67}$ Each state, on a rotating basis, takes its turn as a reviewer and as a subject of review.

${ }^{68}$ See Procedures and rules for the functioning of the Mechanism for the Review of the Implementation of the United Nations Convention against Transnational Organized Crime and the Protocols thereto, Resolution 9/1, Annex, footnote n. 6, supra, paras. 23 and 53.

${ }^{69}$ Unfortunately, States parties to the ATT have decided to exclude civil society from some key aspects of information exchange, most notably the Diversion Information Exchange Forum.

Cross Vol.7 N² (2021) - DOI: http://dx.doi.org/10.54103/cross-16847 
review, as well as best practices, suggestions, and any technical assistance needs identified to improve the implementation and compliance with the Protocol. ${ }^{70}$

The country review report is made available to the Working Group on firearms, an intergovernmental subsidiary body of the Conference of the Parties that is convened every two years. The Working Group, which provides an important forum for exchanges of view among firearms experts, submits its observations (including proposals for recommendations and technical assistance needs) to the Conference of the Parties for its final decisions.

Non-governmental stakeholders may effectively contribute to monitoring and evaluation of State's performance at this stage: for instance, by preparing independent studies and reports, indicating any gaps and challenges in the implementation of the Protocol's provisions under review and existing best practices, as well as their impact on armed violence.

The entire monitoring exercise provided by the Review Mechanism does not produce any ranking or sanctions and aims to help States parties to build their own capacities for implementing and complying with the Protocol. This provides room for collaborative engagement between governments and civil society both in the consultation and assessment phase. The governmental (and non-adversarial) character of the Review Mechanism, combined with the educational function (reciprocal learning) of the peer review, ${ }^{71}$ are expected to facilitate acceptance and the membership to the process, as well as dialogue and mutual trust between States parties to the Protocol, and between them and civil society stakeholders. But, with

\footnotetext{
${ }^{70}$ See Conference of the Parties to the United Nations Convention against Transnational Organized Crime, Tenth Session, Vienna, 12-16 October 2020, Resolution 10/1, Launch of the review process of the Mechanism for the Review of the Implementation of the United Nations Convention against Transnational Organized Crime and the Protocols thereto, cit., Annex II, Blueprint for the list of observations for country reviews.

${ }^{71}$ See Georgios Dimitropoulos, Compliance through collegiality: peer review in international law, Max Planck Institute Luxembourg for International, European and Regulatory Procedural Law, Luxembourg, Working Paper 3, 2014, pp. 25-40; and, more specifically, Christian Ponti, The Review Mechanism of the United Nations Convention Against Transnational Organized Crime and Its Protocols. An Analysis Based on Peer Review Methodology, in The Palermo Convention at Twenty, Institutional and Substantive Challenges, Serena Forlati (ed.), Brill Research Perspectives in Transnational Crime, 2020, pp. 22-38.
} 
the aim to maximizing the effectiveness of the review, transparency and inclusiveness should complement the evaluation. ${ }^{72}$

A separate independent tool to measure armed violence impacts would provide additional information to all stakeholders engaged in the Mechanism. The relation of armed violence impact assessment research efforts to the Review Mechanism will need to be further explored as the Mechanism evolves and States parties become active in it. There are a number of different possibilities to advance a process to "accompany" States parties in their self-assessment,73 as well as in the evaluation phase (for instance, through a wide participation of civil society stakeholders, with the purpose of maximizing the effectiveness of the constructive dialogues ${ }^{74}$ that will take place alongside the meetings of the Working Group on Firearms). This tool would represent an important element in the process to ensure the full potential of the Review Mechanism.

\section{Concluding remarks}

The first global arms control instruments are now twenty years old. Those early agreements have since spawned additional global, regional, and sub-regional frameworks, many of a legally binding character. These, in turn, have generated

\footnotetext{
72 Unfortunately, although transparency is listed as the first guiding principle of the Review Mechanism, this requirement has vanished during negotiations in the Conference, so that States parties to the Protocol may decide not to disclose all data submitted during the evaluation. These limitations call on States parties to show willingness and strong political commitment in supporting transparency and inclusiveness, with the aim to consolidate the legitimacy of the Review Mechanism. ${ }^{73}$ See, for instance, the publication by UNODC Civil Society Team of a toolkit, with the purpose of strengthening the capacity of civil society actors to contribute and to develop strategies (through the engagement with their governments, and in partnership with UNODC) aimed to implement the UNTOC and its supplementing Protocols; see UNODC, Toolkit on Stakeholder Engagement Implementing the United Nations Convention against Transnational Organized Crime (UNTOC), Vienna, 2020.

${ }^{74}$ Notwithstanding their expected marginality in the process (at least on the paper), these meetings will be convened from 2022 only after the adoption of the final reports by the Working Group (therefore, the possibility of an impact on the part of civil society is very low), they nonetheless represent the main engagement point through which civil society can present to and discuss with States parties their observations about implementation and compliance with the Protocol.
} 
significant activity at the national level across multiple domains and authorities, from the passage of new laws criminalizing certain acts to the establishment of enhanced State policies, procedures and mechanisms. The thematic focuses and short-term objectives of these instruments vary: some are broad and inclusive; others relate more narrowly to specific concerns, such as transfer controls, or illicit manufacture and trafficking. Yet they all aim towards the long-term objective of reducing armed violence and promoting safer and more secure societies.

It is time to begin to ask whether the activities generated by these instruments have had any measurable impact on long-term violence reduction objectives. This paper has suggested that the Firearms Protocol of the UNTOC is a strong candidate for impact evaluation given its age, its relatively narrow scope compared to other instruments, and recent progress made in establishing an official implementation evaluation process--the Review Mechanism.

As a new approach in the domain of global arms control instruments, designing and implementing impact evaluations must necessarily face a number of challenges, including the availability of and access to relevant data, the difficulty of attributing activities and outcomes to specific instruments, and controlling for the many relevant factors outside the realm of arms control policymaking. These and other challenges, while significant, should not prevent the attempt to gain what are in effect insights into the ultimate utility of these instruments, measured against the objectives that they were designed to address. Indeed, Agenda 2030 commitments make such an exercise necessary.

This paper has sketched some initial thinking for how armed violence impact tools might be developed to accompany and inform the Firearms Protocol's planned assessment procedures within the Review Mechanism. Clearly, for such a proposal to gain traction, it must be a collaborative and mutually-supportive exercise involving academia, civil society, and national authorities, who must all share an investment in the outcomes. Indeed, only collective commitments among these actors will ensure that the insights generated by impact evaluations are considered and acted upon--and can ultimately contribute to making a difference in the lives of people they are designed to serve. 


\section{Bibliography}

Alvazzi del Frate Anna, Hideg Gergely, LeBrun Emile, Gender Counts: Assessing Global Armed Violence Datasets for Gender Relevance, Small Arms Survey, Briefing Paper, Geneva, March 2020.

Arms Trade Treaty, 2013, in UNTS, vol. 3013, I-52373.

Boister Neil, An Introduction to Transnational Criminal Law, 2nd edn., Oxford University Press, Oxford, 2018.

Dimitropoulos Georgios, Compliance through collegiality: peer review in international law, Max Planck Institute Luxembourg for International, European and Regulatory Procedural Law, Luxembourg, Working Paper 3, 2014.

Duquet Nils, Goris Kevin, Firearms acquisition by terrorists in Europe. Research findings and policy recommendations of Project SAFTE, Flemish Peace Institute Brussels, 18 April 2018.

EU, Implementing Regulation 2018/337 of 5 March 2018 amending Implementing Regulation 2015/2403 establishing common guidelines on deactivation standards and techniques for ensuring that deactivated firearms are rendered irreversibly inoperable, in OJEU, L 65/1, 8 March 2018.

EU, Directive 2017/853 of the European Parliament and of the Council of 17 May 2017 amending Council Directive 91/477/EEC on control of the acquisition and possession of weapons; in OJEU L 137/22, 24 May 2017.

Florquin Nicolas, King Benjamin, From Legal to Lethal: Converted Firearms in Europe, Small Arms Survey, Geneva, April 2018.

Geneva Declaration for Armed Violence and Development, Geneva, 2006.

Geneva Declaration Secretariat, Global Burden of Armed Violence 2015: Every Body Counts, Cambridge University Press, Cambridge, 2015.

Geneva Declaration Secretariat, Global Burden of Armed Violence 2011: Lethal Encounters, Cambridge University Press, Cambridge, 2011.

Geneva Declaration Secretariat, Global Burden of Armed Violence 2008, Geneva Declaration Secretariat, Geneva, 2008.

Hideg Gergely, Alvazzi del Frate Anna, Still Not There: Global Violent Deaths Scenarios, 2019-30, Small Arms Survey, Briefing Paper, Geneva, February 2021.

Hideg Gergely, Alvazzi del Frate Anna, Counting and Characterizing Global Violent Deaths: Current data sources, gaps and possible remedies, Global Registry of Violent Deaths (GReVD), 2020.

Grip Lina, Illegal weapons, gangs and violent extremism in Denmark, Country study for the SAFTE project, Flemish Peace Institute, 2018.

McDonald Glenn, Alvazzi del Frate Anna, Ben Hamo Yeger Moshe, Arms Control 2.0: Operationalizing SDG Target 16.4, Small Arms Survey, Briefing Paper, Geneva, October 2017.

McDonald Glenn, De Martino Luigi, Measuring Illicit Arms Flows: SDG Target 16.4, Small Arms Survey, Research Note No 57, Geneva, May 2016.

Ponti Christian, The Review Mechanism of the United Nations Convention Against Transnational Organized Crime and Its Protocols. An Analysis Based on Peer Review Methodology, in The Palermo Convention at Twenty, Institutional and Substantive Challenges, Forlati Serena (ed.), Brill Research Perspectives in Transnational Crime, 2020.

Ponti Christian, An Appraisal of the European Union Legal Framework on Illicit Firearms Trafficking after Directive 2017/853/EU, in "Rivista di Studi e Ricerche sulla Criminalità Organizzata", 4, 2, 2018. 
Raustiala Kal, Slaughter Anne-Marie, International Law, International Relations and Compliance, in The Handbook of International Relations, Carlsnaes Walter, Risse Thomas, Simonds Beth A. (eds.), SAGE Publications Ltd, London, 2002.

Small Arms Survey 2001. Profiling the Problem. Oxford University Press, Oxford, 2001.

United Nations Convention against Transnational Organized Crime, 2000, in UNTS, vol. 2225, I-39574.

United Nations Protocol against the Illicit Manufacturing of and Trafficking in Firearms, their Parts and Components and Ammunition, 2001, in UNTS, vol. 2326, A-39574.

UN DOC, Outcome of the Seventh Biennial Meeting of States to Consider the Implementation of the Programme of Action to Prevent, Combat and Eradicate the Illicit Trade in Small Arms and Light Weapons in All Its Aspects, A/CONF.192/BMS/2021/CRP.2/Rev.1, para. 92, 30 July 2021.

UN DOC, Conference of the Parties to the United Nations Convention against Transnational Organized Crime, Tenth Session, Vienna, 12-16 October 2020, Resolution 10/1, Launch of the review process of the Mechanism for the Review of the Implementation of the United Nations Convention against Transnational Organized Crime and the Protocols thereto, CTOC/COP/2020/10, 3 November 2020.

UN DOC, Responsiveness of the Firearms Protocol and national legislation to new and emerging threats relating to the illicit manufacturing of and trafficking in firearms, their parts and components and ammunition, Background paper prepared by the Secretariat, CTOC/COP/WG.6/2020/2, 14 January 2020.

UN DOC, Conference of the Parties to the United Nations Convention against Transnational Organized Crime, Ninth Session, Vienna, 15-19 October 2018, Resolution 9/1, Establishment of the Mechanism for the Review of the Implementation of the United Nations Convention against Transnational Organized Crime and the Protocols thereto, CTOC/COP/2018/L.4/Rev.1, 19 October 2018.

UN DOC, Transforming our world: the 2030 Agenda for Sustainable Development, A/Res/70/1, 15 September 2015.

UN DOC, Implementation of the Protocol against the Illicit Manufacturing of and Trafficking in Firearms, Their Parts and Components and Ammunition, supplementing the United Nations Convention against Transnational Organized Crime: consolidated information received from States, Report of the Secretariat, CTOC/COP/2006/8/Rev.1, 12 August 2008.

UN DOC, Report of the Open-ended Working Group to Negotiate an International Instrument to Enable States to Identify and Trace, in a Timely and Reliable Manner, Illicit Small Arms and Light Weapons, A/60/88, 27 June 2005.

UN DOC, Report of the United Nations Conference on the Illicit Trade in Small Arms and Light Weapons in All Its Aspects, A/CONF.192/15,9-20 July 2001.

UN DOC, Resolution n. 1325 on Women, Peace and Security, S/RES/325, 31 October 2000.

UN DOC, United Nations Millennium Declaration, A/RES. 55/2, 18 September 2000.

UN DOC, Report of the Panel of Government Experts on Small Arms, A/Res/ 52/298, 27 August 1997.

UNODC, Global Study on Firearms 2020, Vienna, 2020. 